\author{
DEPARTMENT OF THE INTERIOR \\ UNITED STATES GEOLOGICAL SURVEY
}

PREPARED IN COOPERATION WITH

THE COMMONWEALTH OF KENTUCKY, UNIVERSITY OF KENTUCKY

KENTUCKY GEOLOGICAL SURVEY

WALLACE W. HAGAN, DIRECTOR AND STATE GEOLOGIST

\title{
MAP SHOWING BEDROCK TOPOGRAPHY AND SUBCROP OF SELECTED BEDS BENEATH ALLUVIAL DEPOSITS OF THE REED QUADRANGLE, KENTUCKY-INDIANA
}

By

Ronald L. Norris

MISCELLANEOUS GEOLOGIC INVESTIGATIONS

MAP I-802

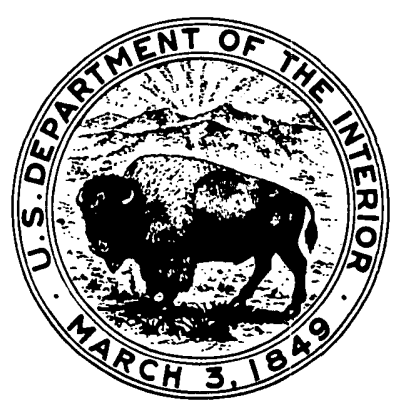

PUBLISHED BY THE U.S. GEOLOGICAL SURVEY 